\title{
Phil Mullan, Beyond Confrontation: Globalists, Nationalists and Their Discontents
}

\author{
Emerald Publishing, 2020, 256p, \$27.99, ISBN: 978-1-83982-563-7 \\ (paperback), ISBN: 978-1-83982-560-6 (online), ISBN: \\ 978-1-83982-562-0 (epub)
}

\section{Philip Hammond ${ }^{1}$ (1)}

Received: 11 August 2020 / Accepted: 23 August 2020 / Published online: 1 September 2020

(c) Fudan University 2020

\begin{abstract}
This article is a book review of Beyond Confrontation: Globalists, Nationalists and Their Discontents by Phil Mullan. Like other writers, Mullan warns of the danger of rising global tensions, but what marks out his contribution is a demystifying historical analysis which identifies the underlying sources of conflict and offers an optimistic and forward-looking vision. The first part of the book examines the emergence of the current rules-based international order in the aftermath of the Second World War, uncovers its inherent flaws, and draws out how it has now become a source of conflict rather than stability. Part two is devoted to debunking myths about trade and trade agreements - particularly the idea that these are central to economic dynamism. Arguing that the relationship between trade and economic growth has been turned upside down, Mullan aims to put it back on its feet. The concluding part sets out some positive proposals for how to reimagine economic policy approaches in ways that could enable root-and-branch renewal and to think afresh about what type of political culture would facilitate such necessary changes.
\end{abstract}

Keywords Globalism · Trade $\cdot$ Protectionism $\cdot$ Democracy $\cdot$ Economic growth

Few can have failed to notice the signs of increasing international tension in recent years. In June 2020 alone, the USA published a list of 20 Chinese companies (most notably Huawei) with alleged military links, announced new visa restrictions on Chinese officials, introduced two new laws addressing China's internal affairs (the Hong Kong Autonomy Act and the Uyghur Human Rights Policy Act), and increased its

Philip Hammond

Phil.Hammond@1sbu.ac.uk

1 School of Arts \& Creative Industries, London South Bank University, 103 Borough Road,

London SE1 0AA, UK 
military presence in the Pacific to three aircraft carriers. The same month, NATO secretary general Jens Stoltenberg declared that "The rise of China is fundamentally shifting the global balance of power, heating up the race for economic and technological supremacy, multiplying the threats to open societies and individual freedoms, and increasing the competition over our values and our way of life".

Britain soon followed suit with a ban on Huawei technology from the UK 5G network. Some in government, such as the China Research Group of Conservative MPs, were already seeking new ways to counter what they see as China's attempt to "reshape the world", and the UK had already announced its own plans to send an aircraft carrier to the South China Sea. But the abrupt U-turn on Huawei was directly driven by US pressure: the tightening of American sanctions against the company made it extremely difficult for Britain to continue the relationship. At the time of writing, in summer 2020, the pressure is now on other European countries to fall into line.

Such events are among many recent illustrations of the two key disruptive trends that Phil Mullan identifies as ushering in a moment of epochal change. First, while the centre of global economic activity has shifted from West to East, the prevailing international political and economic arrangements still reflect the post-1945 world of American hegemony, and second, the resulting East-West friction is complicated and compounded by tensions within the West. Yet, he argues, our ability to understand-let alone respond to-such trends is impeded by a number of mystifications and misunderstandings of globalisation and international trade.

A conventional narrative, for example, is that President Donald Trump's aggressive America-first protectionism has inflamed tensions with a still-growing and increasingly assertive China, and that the answer to both is a redoubled commitment to the "rules-based international order". The further elaboration and enforcement of global rules and trade agreements are widely understood as the only way to contain tariff wars, calm rivalries, and promote stability and prosperity (Stoltenberg, for instance, advocates a "more global approach"). Mullan argues that nothing could be further from the truth: the obsession with established rules is blocking change, and the preoccupation with trade is distracting from the real sources of economic problems.

The book is in three parts. The first examines the emergence of the current rulesbased international order in the aftermath of the Second World War, uncovers its inherent flaws, and draws out how it has now become a source of conflict rather than stability. The architects of post-war order designed a system of international institutions that, they hoped, would prevent a repeat of the catastrophes of the early twentieth century. A key aspect of post-war arrangements was the regulation of trade via the International Monetary Fund, the World Bank and the General Agreement on Tariffs and Trade, on the understanding that it had been trade wars that had led to shooting wars in the past. In fact, Mullan argues, it was "imbalances between economic weight and political influence" that were the key drivers of tension: "the roots of the Second World War lay in the failure to resolve the mismatches that led to the first one". With the eastward shift in economic power, a similar imbalance has emerged today, he argues, so that continued adherence an international order designed to avert conflict is now making it more likely. 
Part Two of the book is devoted to debunking myths about trade and trade agreements-most pointedly, the idea that these are central to economic dynamism. Arguing that the relationship between trade and economic growth has been "turned upside down", Mullan aims to put it back on its feet. The importance attributed to trade, he notes, "corresponds to how capitalist operations really appear, as a social system geared to production for the market". As a result, everything seems to depend on trade, while production is "simply taken for granted as an ever-present technical process". Moreover, as writers such as Henryk Grossmann argued in the early twentieth century, in capitalism's later stage of development the significance of world trade has indeed increased, as a "vital mechanism for offsetting productive decay at home". The export of goods and, crucially, the export of capital became increasingly important as counter-crisis measures. Both practically and intellectually, in other words, the fixation with trade obscures the real productive drivers of growth and distracts from "the West's core economic malfunction: a broken engine of production".

Woven throughout the discussion is an argument about politics. The problem with the rules-based post-war order is not simply that it is now out of alignment with the real dynamics of economic power, but that it institutionalised a system that makes it very difficult to effect change. This was a designed-in feature, rather than a bug: a framework of rules was supposed to ensure peaceful cooperation between states, but also to provide an insulating layer against the disruptions of politics, associated with xenophobia and violence. Influenced by the globalist perspective of neoliberal thought (as chronicled in Quinn Slobodian's 2018 book Globalists), postwar reorganisation institutionalised a system of "double government", whereby the rule of capital and private property ("dominium") was separated from the rule of nation states ("imperium"). The hope was that economic questions would be depoliticised, shielded from the interference of popular democratic politics. The results were clearly visible in Greece in 2015, when European Commission president Jean-Claude Juncker insisted that "there can be no democratic choice against the European treaties". Or as German finance minister Wolfgang Schäuble told Alexis Tsipras's newly elected government, "Elections change nothing. There are rules".

The UK has of course had a similar experience in the protracted wrangling over Brexit (largely centred, inevitably, on trade arrangements). The jury is still out on the eventual shape of Britain's future relationship with Europe and on the programme of Boris Johnson's government, its manifesto plans derailed by Covid-19. But as well as coming up against the constraints of the EU and other globalist bodies, Brexit Britain also faces a problem of imagination. Although there seems to be a great appetite for change in many countries, as indicated by the success of numerous populist campaigns, movements, and political parties in recent years, there is so far little sense of how things might be done differently in the longer term.

The book's concluding part sets out some positive proposals for how to reimagine economic policy approaches in ways that could enable root-and-branch renewal and to think afresh about what type of political culture would facilitate such necessary changes. Elaborating on the theme of his (2017) book, Creative Destruction, Mullan argues that the starting point must be to clear out "zombie" firms and make way for new growth and productive investment — a painful but necessary step, given that 
carrying on in the old way and preserving the structures of the past is, at best, masking problems, if not actively making them worse.

But what is really striking about Beyond Confrontation is the wider discussion of how to foster a culture of what business writers Robert Atkinson and Michael Lind (2018: 17) call "national developmentalism". Since the Covid-19 pandemic, assumptions in Britain and elsewhere have shifted regarding government spending and the role of the state, leading some to hail a break from neoliberalism or even a move towards socialism. Yet, true to his insight that, as indicated above, neoliberal globalist thought was never an anti-state perspective so much as an "anti-mass politics" outlook, Mullan's proposals envisage an important role for the state, but essentially only a supporting one. Instead, the central role has to be played by popular democratic participation in creative, collective decision-making.

As this implies, Mullan mounts a robust defence of the nation state as the only viable "basis for the popular sovereignty of democracy". This is not, however, a narrow nationalism. Mullan reminds us that until relatively recently internationalists supported the principle of national self-determination and understood that "without national freedom the people of a territory would not be able to exercise democracy". Recognising that capital is simultaneously both national and international, Mullan makes a persuasive case that national sovereignty and international cooperation can be complementary, rather than the polar opposites they are so often assumed to be; that assured and confident sovereign states could see others as "partners rather than as beggarly parasites or cheating rivals".

It's not unusual nowadays to find writers warning of the danger of rising global tensions. What marks out Mullan's contribution, however, is a demystifying historical analysis which identifies the underlying sources of conflict, and offers an optimistic and forward-looking vision. It makes for a refreshing contrast to the prevailing fatalism. Beyond Confrontation is an important and urgent book that should be widely read-not least by policy-makers and political leaders of all stripes. Given our current looming economic downturn and rising international tensions, the stakes could not be higher.

\section{Compliance with Ethical Standards}

Conflict of interest The corresponding author states that there is no conflict of interest.

\section{References}

Atkinson, Robert, and Michael Lind. 2018. Big is Beautiful: Debunking the Myth of Small Business. Cambridge, MA: MIT Press.

Mullan, Phil. 2017. Creative Destruction: How to Start an Economic Renaissance. Bristol: Policy Press. Slobodian, Quinn. 2018. Globalists: The End of Empire and the Birth of Neoliberalism. Cambridge, MA: Harvard University Press.

Philip Hammond is Professor of Media \& Communications at London South Bank University. His books include Framing Post-Cold War Conflicts (Manchester, 2007). 